\title{
On the Manufacture of Drift Bottles.
}

By

\section{E. W. Nelson,}

Scientific Superintendent, Fishery Board for Scotland, formerly Senior Naturalist at the Plymouth Laboratory.

With 3 Figures in the Text.

\section{CONTENTS}

\begin{tabular}{|c|c|c|c|c|c|c|c|c|c|}
\hline INTRODUCTION & . & . & . & . & . & ${ }^{\circ}$ & - & . & \\
\hline Bottom Trailers : & . & . & . & & . & ${ }^{\circ}$ & - & . & \\
\hline Specification & . & . & . & & . & . & . & . & \\
\hline Outline of New & Methor & & . & . & & & . & & \\
\hline General Theory & . & . & . & . & $\cdot$ & $\cdot$ & . & & \\
\hline Calculation of $\mathrm{T}$ : & ables & . & & . & - & . & . & & \\
\hline Materials used & . & . & . & . & . & . & . & & \\
\hline Detailed Procedu & & . & . & . & & . & . & & \\
\hline Surface Drifters: & . & . & . & & - & . & . & . & \\
\hline Materials . & . & . & . & . & . & & . & . & \\
\hline Procedure . & . & . & & . & . & & . & & \\
\hline
\end{tabular}

Estimated Quantities . . . . . . . . . . . . 716

\section{INTRODUCTION}

In the spring of 1920 the Ministry of Agriculture and Fisheries approached the Marine Biological Association of the United Kingdom with a view to the Association undertaking the manufacture of a large number of "Drift Bottles," to be used in an extensive research into the resultant movements of the waters of the North Sea.

These "Drift Bottles" were to be of two kinds, viz., one to float on the surface and the other to trail along the bottom. The former type of instrument has been in use from an early date and presents no very 
special features, the latter type was originated by Dr. G. P. Bidder and called a "Bottom Trailer." A successful series of experiments was carried out by him in the North Sea with bottles made to his specification.*

The "Bottom Trailer" is a glass bottle containing a printed postcard for the use of the finder and a label which can be read through the glass instructing the finder to "Break the Bottle." The neck of the bottle carries a straight wire tail pointing in the direction of the long axis of the bottle. The bottle is adjusted so as to have a small negative buoyancy in sea-water. When the bottle is dropped overboard it sinks to the bottom, tail first, and when the tip of the tail touches the bottom drifts with the current in that position.

The method used in the manufacture of the original bottles was to adjust them by trial and error in a tank of sea-water of known salinity, and to correct for temperature by adding a small measured length of wire. The bottle, containing a definite make-weight, was placed upside down in the sea-water and shot were added to the bottom until the bottle was almost sinking. After removing the make-weight the postcard and label were inserted, and the neck above the end of the rolled postcard was packed with cotton-wool. The shot were dried, placed on the top of the wool, the bottle was stoppered, the stopper sealed with marine glue, and the tail fitted. The bottle was again placed in the sea-water and wire was added to the neck until the bottle would neither sink nor float. Entering a table with the temperature of the sea-water as argument, a length of wire was found which, when added to the neck, completed the adjustment.

The handling of the bottle in sea-water and the necessary drying was found to be troublesome. Difficulty was also experienced in changes in temperature due to warmth from the hands when adjusting the bottles.

When the Director of the Association placed this matter into my hands, I considered that the required output could not be obtained without great difficulty unless the method of adjustment was improved, and therefore started experiments with this end in view.

As it would seem probable that "Bottom Trailers" may be used to a much greater extent in the near future, it is thought that the methods adopted, and herein described, may be of interest to others.

I am indebted to Mr. E. Ford for the drawing of Figs. 1 and 2, and to the Proprietors of The Western Evening Herald for the block of Fig. 3 .

* Bidder, G. P., “Conseil Internat. L'Expl. de la Mer." Rapports et Proc. Verb. IV, July, 1905, Appendix F, p. 102, Copenhagen, 1905. Loc. cit., VI, November, 1906, Annexe C, p. xxxv, Copenhagen, 1906. 


\section{BOTTOM TRAILERS.}

\section{Specification.}

Before commencing the manufacture of "Bottom Trailers," it is necessary to decide on a standard to which they shall be made. Dr. Bidder, for bottles to be used in the North Sea, finally adopted a negative buoyancy of $1.7 \mathrm{gm}$. in sea-water of specific gravity 1.02750 at $8^{\circ} \mathrm{C}$. It should be noted that it is necessary to fix upon a standard temperature as well as a specific gravity in situ $\left(\sigma_{t}\right)$ since a correction must be applied for the expansion of the bottle itself. Dr. Bidder also adopted a wire tail two feet $(610 \mathrm{~mm}$.) long, measured clear of the neck of the bottle.

Since these bottles proved very successful, and no further data were available, it was decided to make this series to the same specification.

It is, therefore, required that the mass of the "Bottom Trailer" shall bear such a relation to its volume at $8^{\circ} \mathrm{C}$. that an equal volume of seawater at the same temperature and of specific gravity 1.02750 shall weigh $1.7 \mathrm{gm}$. less.

\section{Outline of New Method.}

The procedure described below is dependent upon a supply of bottles of which the external volume is constant within certain limits. Bottles such as are sold to the manufacturers of mineral waters are made by blowing molten glass into iron moulds. Several moulds are generally used for any one type of bottle, and these different moulds will, as a rule, slightly differ in size. It was found that bottles from each separate mould could be identified and sorted into batches by a careful examination of the marks left in the surface of the glass by the mould. It would be preferable to arrange with the manufacturers for the whole supply to be made in one definite mould.

Although it was found that the external volume of the bottles chosen was sufficiently constant, their weight differs greatly on account of the varying amounts of glass in each. The actual weight, however, of the original bottles within fairly wide limits is not material.

A supply of suitable bottles having been obtained, the procedure is as follows :- The postcard and label are placed in the bottle with a pad of cotton-wool above, and the whole made up to a given constant weight in air by the addition of shot on top of the cotton-wool. The bottle is then corked, sealed, and fitted with the tail. In this condition the bottle is weighed in air and then immersed in distilled water. With these weights, the temperature of the distilled water, and the weight of a metre of the adjusting wire as arguments, the length of wire to be added to the 

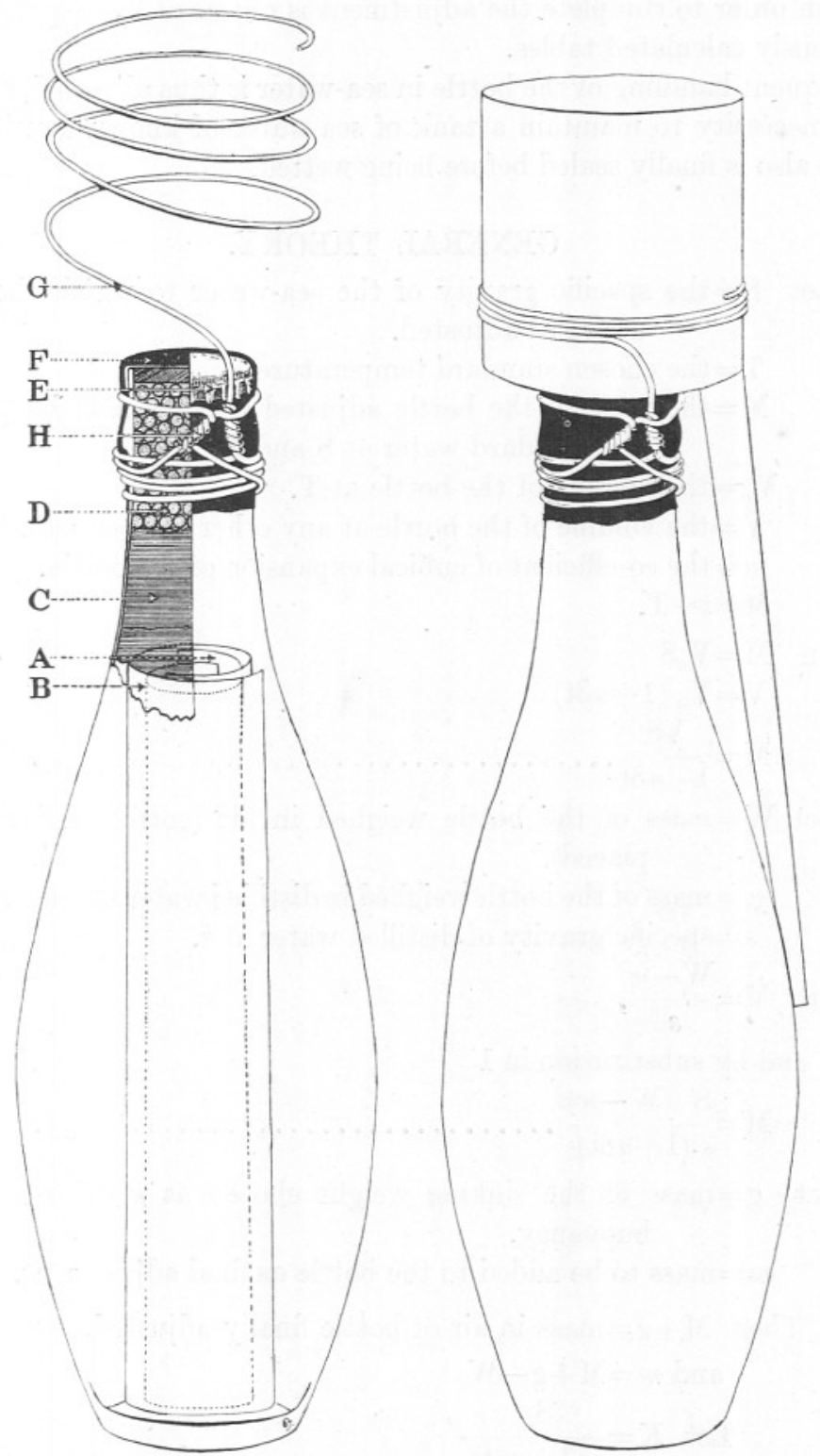

FIG. 1.-A. Rolled postcard.

B. Label.

C. Cotton-wool.

D. Shot.

E. Metal cap.

F. Sealing of marine glue.

G. Tail coiled for adjusting and packing to be straightened before use. H. Adjusting wire.

FIG. 2.-Shows method of coiling wire. 
neck in order to complete the adjustment is obtained by inspection from previously calculated tables.

Frequent handling of the bottle in sea-water is thus obviated, and there is no necessity to maintain a tank of sea-water of known density. The bottle also is finally sealed before being wetted.

\section{GENERAL THEORY.}

Let $\mathrm{S}=$ the specific gravity of the sea-water to which the bottles are to be adjusted.

$\mathrm{T}=$ the chosen standard temperature.

$\mathrm{M}=$ the mass of the bottle adjusted to have zero buoyancy in the standard water at $\mathrm{S}$ and $\mathrm{T}$.

$\mathrm{V}_{0}=$ the volume of the bottle at $\mathrm{T}$.

$\mathrm{V}=$ the volume of the bottle at any other temperature $t$.

$a=$ the co-efficient of cubical expansion of the bottle.

$\delta \mathrm{t}=\mathrm{t}-\mathrm{T}$.

Then $\mathrm{M}=\mathrm{V}_{0} \mathrm{~S}$

$\mathrm{V}=\mathrm{V}_{0}(1+a \delta \mathrm{t})$

$\mathrm{M}=\frac{\mathrm{VS}}{1+a \delta \mathrm{t}}$.

Let $\mathrm{W}=$ mass of the bottle weighed in air (corrected for air displaced).

$w=$ mass of the bottle weighed in distilled water at temperature $t$. $s=$ specific gravity of distilled water at t.

Then $\mathrm{V}=\frac{\mathrm{W}-w}{s}$,

and by substitution in 1

$$
\mathrm{M}=\frac{\mathrm{S}(\mathrm{W}-w)}{s(1+a \delta \mathrm{t})}
$$

Let $\mathrm{g}=$ mass of the sinking weight chosen as standard negative buoyancy,

$m=$ mass to be added to the bottle as final adjustment.

Then $\mathrm{M}+\mathrm{g}=$ mass in air of bottle finally adjusted,

and $m=\mathrm{M}+\mathrm{g}-\mathrm{W}$

Let $\mathrm{K}=\frac{\mathrm{S}}{s(1+a \delta \mathrm{t})}$

Then from (2) $m=\mathrm{K}(\mathrm{W}-w)-\mathrm{W}+\mathrm{g} \ldots \ldots \ldots \ldots \ldots .(3)$

Let $\mathrm{K}=\mathrm{K}_{0}+\delta \mathrm{K}$

$\mathrm{W}=\mathrm{W}_{0}+\delta \mathrm{W}$

$w=w_{0}+\delta w$

where $\mathrm{K}_{0}, \mathrm{~W}_{0}$, and $w_{0}$ are mean values of $\mathrm{K}, \mathrm{W}$, and $w$. 
Then by substitution in (3) and rearranging

$$
\begin{aligned}
& m=\mathrm{K}_{0}\left(\mathrm{~W}_{0}-w_{0}\right)-\mathrm{W}_{0}+\mathrm{g}-\mathrm{K}_{0} \delta w+\quad(=\mathrm{a}) \\
& \left(\mathrm{K}_{0}-1\right) \delta \mathrm{W}+\quad(=\mathrm{b}) \\
& \left(\mathrm{W}_{0}-w_{0}\right) \delta \mathrm{K}+\quad(=\mathrm{c}) \\
& (\delta \mathrm{W}-\delta w) \delta \mathrm{K} \ldots \ldots \ldots \ldots \ldots(4)
\end{aligned}
$$

or neglecting the last term,

$$
m=\mathrm{a}+\mathrm{b}+\mathrm{c} \text {. }
$$

Let $n=$ length in $\mathrm{mm}$. of $1 \mathrm{gm}$. of adjusting wire in seawater at $\mathrm{S}$ and $\mathrm{T}$.

$\mathrm{L}=$ length in $\mathrm{mm}$. of $m \mathrm{gm}$. of wire.

Then $\mathrm{L}=m n$.

Let $n=\mathrm{n}_{0}+\delta n$ where $\mathrm{n}_{0}$ is a mean value o: $n$.

$$
\text { Then } \begin{aligned}
\mathrm{L} & =m\left(\mathrm{n}_{0}+\delta n\right) . \\
\text { Let } & =\mathrm{n}_{0} \mathrm{a} \\
\mathrm{B} & =\mathrm{n}_{0} \mathrm{~b} \\
\mathrm{C} & =\mathrm{n}_{0} \mathrm{c} \\
\mathrm{D} & =m \delta n
\end{aligned}
$$

Then $\mathrm{L}=\mathrm{A}+\mathrm{B}+\mathrm{C}+\mathrm{D}$

a form convenient for practical use.

\section{Calculation of Tables.}

It was found that the external volume of the bottles was sufficiently constant to permit neglecting the last term of equation (4). Since the method used in preparing the bottles provides that $W$ shall be practically constant $\delta \mathrm{W}$ will always be small. $\delta \mathrm{K}$ depends only on variation in the temperature of the distilled water in which the bottles are weighed and will not be large under ordinary laboratory conditions. The variation in the volume of the bottles will be shown in the factor $\delta w$. In equation (5) above, therefore, the term $\mathrm{A}$, which includes the variable $\delta w$, can be considered as the main result to which the corrections B, C, and D, should be applied.

$$
\mathrm{K}=\frac{\mathrm{S}}{s(1+a \delta \mathrm{t})}
$$

expanding and neglecting quantities of the second and higher order of magnitudes where less than $0 \cdot 0000005$

$$
\begin{aligned}
\mathrm{K} & =[1+(\mathrm{S}-1)]\left[1+(1-s)+(1-s)^{2}\right][1-a \delta \mathrm{t}] \\
& =\mathrm{S}+(1-s)+(1-s)^{2}-a \delta \mathrm{t}-a \delta \mathrm{t}(1-s)+(\mathrm{S}-1)(1-s-a \delta \mathrm{t})
\end{aligned}
$$

NEW SERIES.-VoL. XiI. No. 4. OCTOBER, 1922. 
Table $\mathrm{K}$ has been calculated for the following values of the constants :-

$$
\begin{aligned}
& \mathrm{S}=1 \cdot 02750 \\
& \mathrm{~T}=8 \cdot 0^{\circ} \mathrm{C} . \\
& a=0 \cdot 000026
\end{aligned}
$$

The tabular values $=1000(\mathrm{~K}-1)$

\begin{tabular}{|c|c|c|}
\hline t & $1000(\mathrm{~K}-1)$ & $\delta \mathrm{K} \times 10^{6}$ \\
\hline $8 \cdot 0^{\circ} \mathrm{C}$ & $27 \cdot 627$ & -644 \\
\hline$\cdot 5$ & $27 \cdot 647$ & -624 \\
\hline $9 \cdot 0$ & $27 \cdot 671$ & -600 \\
\hline 5 & $27 \cdot 695$ & -576 \\
\hline $10 \cdot 0$ & $27 \cdot 725$ & -546 \\
\hline .5 & $27 \cdot 758$ & -513 \\
\hline $11 \cdot 0$ & $27 \cdot 794$ & -477 \\
\hline .5 & $27 \cdot 834$ & -437 \\
\hline $12 \cdot 0$ & $27 \cdot 877$ & -394 \\
\hline$\cdot 5$ & $27 \cdot 912$ & -348 \\
\hline $13 \cdot 0$ & $27 \cdot 960$ & -298 \\
\hline .5 & $28 \cdot 026$ & -245 \\
\hline $14 \cdot 0$ & $28 \cdot 084$ & -187 \\
\hline .5 & $28 \cdot 143$ & -128 \\
\hline $15 \cdot 0$ & $28 \cdot 206$ & -65 \\
\hline .5 & $28 \cdot 271$ & 0 \\
\hline $16 \cdot 0$ & $28 \cdot 339$ & 68 \\
\hline .5 & $28 \cdot 411$ & 140 \\
\hline $17 \cdot 0$ & $28 \cdot 486$ & 215 \\
\hline .5 & $28 \cdot 566$ & 295 \\
\hline $18 \cdot 0$ & $28 \cdot 646$ & 375 \\
\hline .5 & $28 \cdot 729$ & 458 \\
\hline $19 \cdot 0$ & $28 \cdot 815$ & 544 \\
\hline .5 & 28.906 & 635 \\
\hline $20 \cdot 0$ & 28.996 & 725 \\
\hline$\cdot 5$ & $29 \cdot 093$ & 822 \\
\hline $21 \cdot 0$ & $29 \cdot 190$ & 919 \\
\hline .5 & $29 \cdot 290$ & 1019 \\
\hline $22 \cdot 0$ & $29 \cdot 394$ & 1123 \\
\hline
\end{tabular}

Taking $\mathrm{K}_{0}$ as the value of $\mathrm{K}$ at $15 \cdot 5^{\circ} \mathrm{C} ., \delta \mathrm{K} \times 10^{6}$ has also been tabulated.

TABLE K. 
TABLE A.

Find experimentally the mean value of $\mathrm{W}$, the weight in air, and $w$, the weight in distilled water, of a series of bottles made up to any given sufficient weight, and fitted with tail, etc., as in the finished article.

Then from (2) $\mathrm{M}=\mathrm{K}(\mathrm{W}-w)$

Calculate $\mathrm{M}+\mathrm{g}$ which will be the mean weight of the correctly adjusted bottle. Allowing $3 \mathrm{gm}$. for the addition of adjusting wire, $\mathrm{M}+\mathrm{g}-3$ will be the weight to which the bottle should be made up when ready for final adjustment.

It will be found convenient to choose $W_{0}$ so that its apparent value, without correcting for air displaced, will be a whole number. The nearest value to $\mathrm{M}+\mathrm{g}-3$ which fulfils this condition will therefore be chosen.

Example :-

$\begin{array}{rr}\text { Mean apparent W } & 521 \cdot 82 \\ \text { Add for air displaced } & 0 \cdot 53 \\ \text { Mean W } & \frac{522 \cdot 35}{12 \cdot 45} \\ \text { Mean } w & \frac{509 \cdot 90}{524 \cdot 3} \\ \therefore \mathrm{W}-w & \text { at } 15 \cdot 5^{\circ} \mathrm{C} \text {. } \\ \mathrm{K}_{0}(\mathrm{~W}-w) & \frac{1 \cdot 7}{526 \cdot 0} \\ +\mathrm{g} & \frac{3}{523 \cdot 0} \\ \mathrm{M}+\mathrm{g} & -3\end{array}$

Therefore let $\mathrm{W}_{0}=522 \cdot 53$

which gives apparent $W_{0}=522 \cdot 0$

$$
\begin{array}{rr}
\mathrm{W}_{0} & \overline{\overline{522 \cdot 53}} \\
\mathrm{~W}-w & \overline{509 \cdot 90} \\
\therefore w_{0} & \overline{\underline{12 \cdot 63}} \\
\mathrm{~W}_{0} & \overline{522 \cdot 53} \\
w_{0} & \underline{12 \cdot 6} \\
\therefore \mathrm{W}_{0}-w_{0} & \underline{509 \cdot 93 .}
\end{array}
$$

From equation (4) and (5) above :-

$$
\mathrm{A}=\mathrm{n}_{0} \mathrm{a}=\mathrm{n}_{0}\left[\mathrm{~K}_{0}\left(\mathrm{~W}_{0}-w_{0}\right)-\mathrm{W}_{0}+\mathrm{g}-\mathrm{K}_{0} \delta w\right]
$$

Let $l=\mathrm{n}_{0}\left[\mathrm{~K}_{0}\left(\mathrm{~W}_{0}-w_{0}\right)-\mathrm{W}_{0}+\mathrm{g}\right]$

Calculate $l$ **

* For value of $n_{0}$ see p. 705 . 
Calculate $\mathrm{n}_{0} \mathrm{~K}_{0} \delta w$ for each value of $\delta w$ differing by $0 \cdot 1 \mathrm{gm}$.

Calculate $\mathrm{A}=l-\mathrm{n}_{0} \mathrm{~K}_{0} \delta w$

Tabulate A with $w$ to $0 \cdot 1 \mathrm{gm}$. as argument.

Example :-

$$
\begin{aligned}
\mathrm{n}_{0} & =79 \cdot 66 \\
\mathrm{~K}_{0} & =1 \cdot 028271 \\
\mathrm{~W}_{0} & =522 \cdot 53 \\
w_{0} & =12 \cdot 6 \\
\mathrm{~g} & =1 \cdot 7 \\
\text { If } \quad w & =10 \cdot 6 \\
\delta w & =10 \cdot 6-12 \cdot 6 \\
& =-2 \cdot 0
\end{aligned}
$$

Then $\quad l=280 \cdot 08$

$$
\mathrm{n}_{0} \mathrm{~K}_{0} \delta w=-163 \cdot 82
$$

and $\mathrm{A}=l-\mathrm{n}_{0} \mathrm{~K}_{0} \delta w=443 \cdot 90$

With $w=10 \cdot 6 \mathrm{gm}$. as argument, Table A would give $444 \mathrm{~mm}$. as the length of adjusting wire to be added.

It has been found that a range of $10 \mathrm{gm}$. in the value of $w$ is sufficient for Table A. As $w$ increases, A decreases; the upper limit of the table should be where the value of $A$ is about $-150 \mathrm{~mm}$.

\section{TABLE B.}

Calculate $\quad \mathrm{B}=\mathrm{n}_{0}\left(\mathrm{~K}_{0}-1\right) \delta \mathrm{W}$.

Tabulate $\mathrm{B}$ with apparent $\mathrm{W}$ as argument for values of $\delta \mathrm{W}$ differing by $1 \mathrm{gm}$.

Example :-

$$
\mathrm{W}=526 \cdot 0 \mathrm{gm} \text {. }
$$

Constants as above :-

Correction for air displaced

$$
\mathrm{W}_{0}=522 \cdot 53
$$

$$
\text { Apparent } \mathrm{W}_{0}=522 \cdot 00
$$

$$
\begin{array}{r}
\text { Therefore } \delta \mathrm{W} \\
\text { and } \mathrm{n}_{0}\left(\mathrm{~K}_{0}-1\right) \times 4 \cdot 0 \\
\quad 9 \cdot 0
\end{array}
$$




\section{TABLe C.}

CaIculate $\quad \mathrm{C}=\mathrm{n}_{0}\left(\mathrm{~W}_{0}-w_{0}\right) \delta \mathrm{K}$

Tabulate $\mathrm{C}$ with temperature of water in which bottle was weighed as argument for values of $\delta$ t differing by $0.5^{\circ} \mathrm{C}$.

$$
\begin{aligned}
& \text { Example :- } \\
& \qquad \begin{aligned}
\mathrm{t} & =16 \cdot 5^{\circ} \\
\delta \mathrm{K}(\text { page } 706) & =0 \cdot 000140 \\
\therefore \mathrm{n}_{0}\left(\mathrm{~W}_{0}-w_{0}\right) \delta \mathrm{K} & =6
\end{aligned}
\end{aligned}
$$

\section{Table D.}

Let $d=$ weight of $1 \mathrm{~m}$. of copper wire in air

Then $0.8841 d=$ weight of $1 \mathrm{~m}$. of copper wire in sea-water under standard conditions.

Therefore $\quad n=\frac{1000}{0 \cdot 8841 d}$

Determine a mean value for $d$ by weighing a considerable measured length of the wire to be used, the corresponding value of $n$ gives $\mathrm{n}_{0}$.

Calculate the values of $n$ corresponding to values of $d$ differing by $0 \cdot 1 \mathrm{gm}$. and hence $\delta n$ from $\delta n=n-\mathrm{n}_{0}$.

Calculate the value of $m$ corresponding to values of $m \mathrm{n}_{0}(=\mathrm{A}+\mathrm{B}+\mathrm{C})$ for each whole $100 \mathrm{~mm}$.

Calculate $m \delta n$ from values thus obtained and tabulate with $d$ and $\mathrm{A}+\mathrm{B}+\mathrm{C}$ as arguments.

Example :-

$$
\begin{aligned}
\text { mean } d & =14 \cdot 2 \\
\text { therefore } \mathrm{n}_{0} & =79 \cdot 66 \\
\text { If } d & =14 \cdot 0 \\
n & =80 \cdot 8 \\
\text { and } \delta n & =1 \cdot 14 \\
\text { If } m \mathrm{n}_{0} & =500 \\
m & =6 \cdot 29 \\
\text { therefore } m \delta n & =7
\end{aligned}
$$

the tabular value under $d=14 \cdot 0$ and $\mathrm{A}+\mathrm{B}+\mathrm{C}=500$. 


\section{MATERIALS USED.}

In order that success may be obtained in using this method of manufacture, it is essential that the ratio of the volume to the mass of the bottle after being sealed should fall within certain fairly restricted limits. Care should be taken, therefore, to obtain materials which are as uniform as possible, and to adopt a definite routine in using them.

The following details of the materials used in the manufacture of this batch of " drift bottles" are given as a general guide.

Bottles. " $10 \mathrm{oz}$. Flat Bottom, Crown Mouth, Sodas," obtained from Messrs. Kilner Bros., London, who, in order that the external volume should be as constant as possible, kindly arranged that the bottles should as far as possible be made in one particular mould. On the average these bottles have an external volume of $510 \mathrm{cc}$. and weigh $480 \mathrm{gm}$. If the ratio of volume to weight is too small, a large number of rejects for excessive weight will be obtained, if too large an unnecessary amount of shot will be used.

Corks. "Crown Corks" are circular discs of tinned sheet-iron, with edges bent over and crenelated. On the inside is a circular piece of sheet cork. The corks are put on the bottles by means of a machine which is made for this purpose.*

This type of sealing is very largely used for Mineral waters.

Sealing. Marine Glue, No. 2 brand, made by Alfred Jeffrey and Co., London. In order to render the sealing less liable to be chipped, a small quantity, about $1 \%$, of tallow is added to the melted glue.

Wire. Good quality copper wire used both for making the tails and for finally adjusting the bottles. This wire is technically known as "Soft Drawn " British Wire, Gauge No. 17, diameter 1.42 mm., weight 14.2 gm. per metre. To obtain uniformity in weight for length a large quantity should be obtained from one drawing.

Shot. Ordinary No. 4 lead shot weighing about 6 to 1 gramme.

Cards. In each box containing twenty-five of each sort of drifter, two postcards are placed for the use of the officer who liberates the bottles. One is addressed to the Ministry of Agriculture and Fisheries and the other to the Marine Biological Association. The other side is printed thus :-

* We are indebted to Messrs. "The Plymouth Breweries" for the loan of a corking machine. 


\section{INTERNATIONAL FISHERY INVESTIGATIONS.}

Name of Lightship?

Name and Rank of Officer-in-Charge?

Year and Date of Liberation of Bottles?

Day and Time of Liberation?

Bottles put out?

Surface numbers..................... to inclusive.

Bottom numbers............ to .......... inclusive.

Remarks, if any?

Both kinds of drifters contain a label printed in large black type on a red ground :-

BREAK THE BOTTLE.

CASSEZ LA BOUTEILLE.

BREK DE FLESCH. 5692

BRECHEN DIE FLASCHE.

\section{SLAA FLASKEN ITU.}

The fronts of the postcards used in both the surface and bottom drifters are the same :-

\section{POST CARD.}

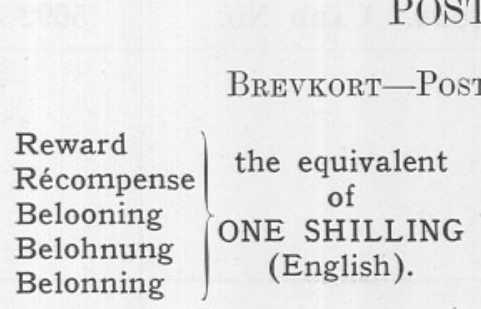

Please fill up blanks on the back of this card and post it.

Prière de répondre aux questions sur l'autre face de cette carte, et de la remettre en poste.

Wees zoo goed dese kaart intevullen en aan de post overgeven.

Bitte die nötigen Einträge an der Rückseite zu machen, und die Kart der Post zu übergeben.

Hav den Godhed at besvare Sporgsmaalene paa Bagsiden af dette Kortet og send det med Posten.

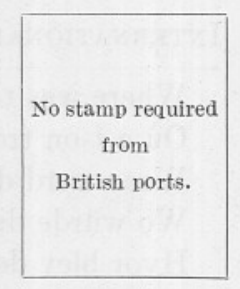

THE FISHERIES SECRETARY,

Ministry of Agriculture

and Fisheries,

43, Parliament Street, LONDON, S.W. I, ENGLAND. 
The back of the postcard placed in a bottom trailer :-

International Fishery Investigations. Card No.

5692 B.

Where was this bottle found ?

Où a-t-on trouvé cette bouteille?

Waar werd deze flesch gevonden ?

Wo würde die Flasche gefunden ?

Hvor blev denne Flaske funden?

Date when found

A quelle date l'a-t-on trouvée?

Op welken dag

Datum des Fundes

Hvilken Dato blev den funden ?
At what depth ?

A quelle profondeur?

Welke diepte?

Aus welcher Tiefe?

I hvilken Dybdi ?

\section{Name of Ship}

Nom du vaisseau

Scheeps naam

Namen des Schiffes

Skibets Navn
Was it taken in a trawl ?

S'est-elle trouvée dans un chalut ?

Werd ze in een schrob-net gevonden ?

Würde sie in ein Trawl-nets erhalten ?

Blev den funden i et Trawl eller Snurrevaad ?

What length of wire tail had it ?

Quelle est la longueur du fil de métal ?

Hoe lang was de drood aan de flesche ?

Wie lang war der freie Draht an der Flasche ? Hvad Længde havde Slæbetrossen ?

Name and address of finder

Nom et adresse de celui qui la trouve

Naam en adres van den vinder

Namen und Adresse des Finders

Finderens Navn og Adresse

The back of the postcard placed in a surface drifter :-

International Fishery Investigations. Card No.

$5692 \mathrm{~S}$.

Where was this bottle found?

Où a-t-on trouvé cette bouteille?

Waar werd deze flesch gevonden?

Wo würde die Flasche gefunden?

Hvor blev denne Flaske funden?

Date when found

A quelle date l'a-t-on trouvée?

Op welke dagteekening

Datum des Fundes

Hvilken Dato blev den funden?

Name and address of finder ..

Nom et adresse de celui qui la trouve

Naam en adres van den vinder

Namen und Adresse des Finders

Finderens Navn og Adresse .. 


\section{DETAILED PROCEDURE.}

The following gives, in detail, the procedure adopted by us in making "Bottom Trailers." The weights mentioned apply to the particular type of bottle used and are only given to simplify the explanation.

1. The bottles are sorted into three batches :- over $500 \mathrm{gm}$. are discarded, $460 \mathrm{gm}$. to $500 \mathrm{gm}$. are used for "bottom trailers," and under $460 \mathrm{gm}$. are used for surface drifters. This sorting is easily and quickly done by means of two pairs of pan scales, each weighed to one limit, viz., $500 \mathrm{gm}$. and $460 \mathrm{gm}$.

2. The sorted bottles are cleaned with a bottle brush and duster.

3. The postcard is rolled on a length of glass tubing, the label is rolled on top of the postcard, and both are slipped off the tube into the bottle.

4. The neck of the bottle above the rolled postcard is loosely filled with cotton wool.

5. The bottle is placed on a balance weighted to $506 \mathrm{gm}$. and shot added until equilibrium is reached. The type of balance employed is that used in banks for the weighing of bullion. A small tray fixed in the chains suspending the pan on which the bottle is placed will be found convenient for receiving the shot, and a tin funnel fitting over the neck facilitates the introduction of the shot into the bottle. This funnel should be fitted with a small wedge-shaped ring of cork to prevent shot catching on the glass lip. If necessary, the cotton wool should be pressed down with a length of wire to leave just sufficient room for the shot.

6. The Crown Cork is fitted with the machine.

7. The neck of the bottle is dipped twice into melted marine glue; the first dip to just cover the metal part of the cork, the second to immerse the neck for about a depth of 1 in. $(25 \mathrm{~mm}$.). The bottle is twisted round rapidly for a few seconds and dipped into cold water to harden the glue.

8. A wire tail, previously cut to a fixed length allowing sufficient to go round the neck of the bottle, is fitted to the neck by twisting up the short end so as to leave 2 feet clear beyond the stopper.* The tail is made into a coil of about 2 ins. diameter by twisting it loosely round a short cylinder of wood fitted with a handle, which is held in the same hand as the bottle (Fig. 2). This method of coiling the tail leaves the neck free to receive the adjusting wire to be added subsequently.

* Care should be taken not to strain the wire when twisting so as to make the tail liable to break off. 
9. The bottle is weighed in air to the nearest $0.5 \mathrm{gm}$. and the weight, $W$, recorded in the notebook against the serial number.

10. The bottle is weighed to the nearest $0.05 \mathrm{gm}$. immersed in distilled water and the weight, $w$, and temperature, $\mathrm{t}$, are noted.

A considerable volume of water is used so as to avoid rapid changes in temperature. The bottle is held upside down in the water by means of a copper ring, which is slung from the balance by means of three short copper wire stays and above them waterproof silk.

11. One metre of the copper wire used for the final adjustment is weighed to $0 \cdot 1 \mathrm{gm}$. and the weight, $d$, noted. This measurement is only made occasionally as a check, say after every twenty bottles adjusted.

12. The tables are entered with $w, \mathrm{~W}, \mathrm{t}$, and $d$, as arguments, and the resultants added together $(\mathrm{A}+\mathrm{B}+\mathrm{C}+\mathrm{D})$ give the length of wire in millimetres to be used as the final adjustment.

13. A length of wire equal to the sum of the resultants is measured along a metre rule, cut off, and twisted round the neck of the bottle, giving extra security to the tail. If the sum happens to be a minus quantity, a result which should be avoided as much as possible, this length, if small, is cut off from the end of the tail. In no case has more than $150 \mathrm{~mm}$. been so cut off. The bottle is now finally adjusted and only requires the tail to be straightened before liberation.

\section{SURFACE DRIFTERS.}

These instruments are required to float on the surface, submerged as much as possible to reduce windage, but with sufficient buoyancy to ensure that they will not sink in water of the lowest density into which they may drift. Any bottle with sufficient displacement for its weight is suitable.

Our experience with "bottom trailers" proved that the external volume of a given batch of bottles is practically constant. It was decided, therefore, to make up any one type of bottle to be used as a "surface drifter " to a given fixed weight. It was also decided to make the " surface drifters " with an average positive buoyancy of $3 \mathrm{gm}$.

The following example will show how the weight to which the bottle should be loaded before sealing is calculated :- 


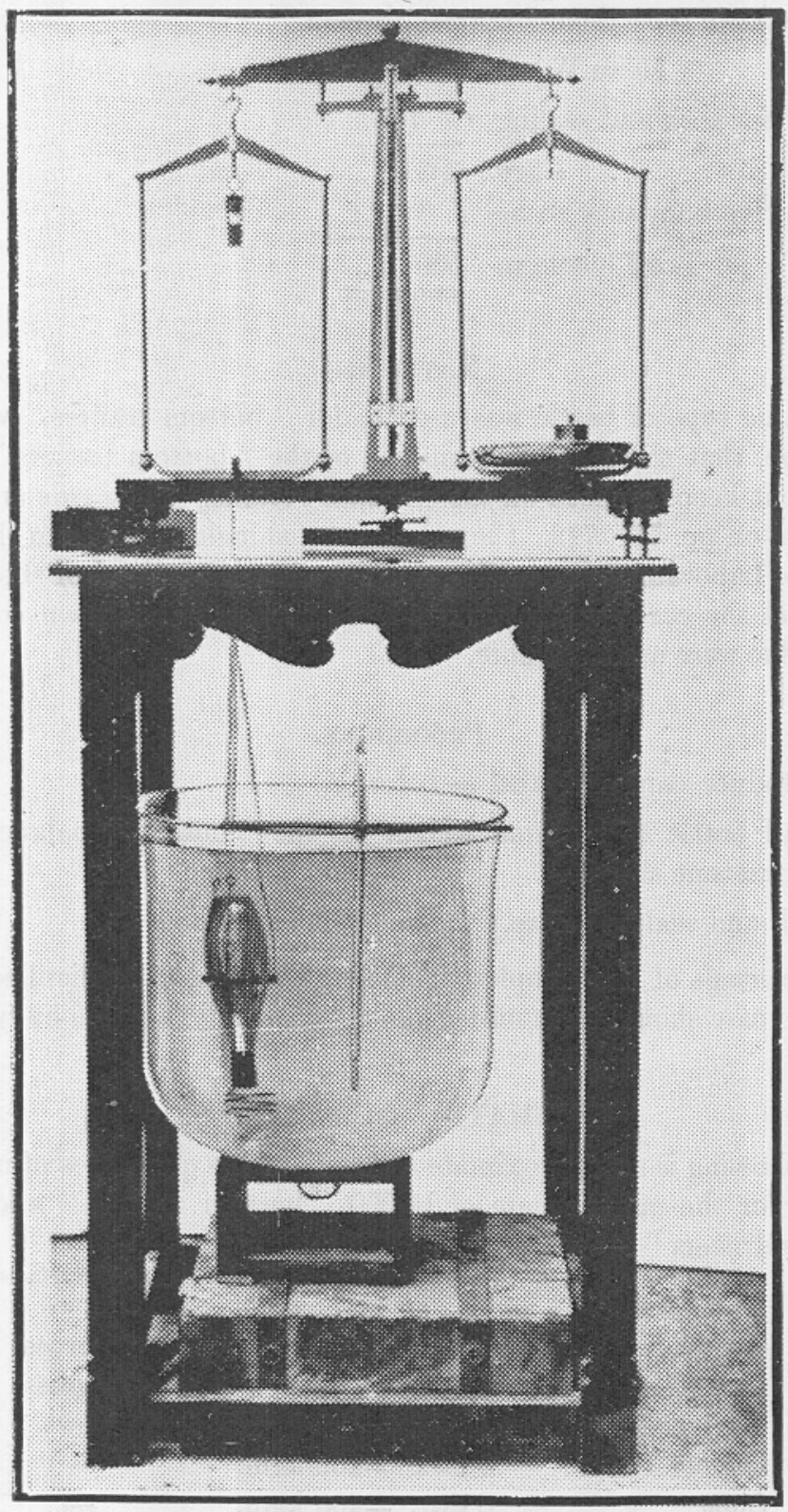

FrG. 3.-Apparatus used for weighing a "bottom trailer" immersed in water. 
A series of bottles are overloaded, corked, sealed, and weighed in air and water as in the case of " bottom trailers."

$$
\text { Mean } \mathrm{W}-w=509 \cdot 9 \mathrm{gm} \text {. }
$$

Allow for cork and sealing $\quad 7 \cdot 0$,

$\begin{array}{rrr}\text { = say } & 503 & \text { " } \\ \text { Positive buoyancy to be } & 3 & , \\ \therefore \text { Load bottle to } & 500 \quad,\end{array}$

\section{Materials.}

The same type of bottle was used as for "bottom trailers," with this advantage, that the constant weighing of the "bottom trailers" during adjustment keeps a check on the external volume. The cards and labels are shown on pp. 711, 712. Clean limestone shingle taken from the beach below the Laboratory was used to load the bottles instead of shot, which would soil the cards unless waxed into the bottom. Crown corks and marine glue were used as before.

\section{Procedure.}

1. Introduce card and label as before.

2. Load bottle to required weight on the "bullion" balance, using limestone shingle.

3. Cork and seal as before.

A percentage of the completed bottles were tested in distilled water, and in no case should have more than a very small negative buoyancy.

\section{ESTIMATED QUANTITIES.}

The following is an approximate estimate of the quantities of materials required for the manufacture of 10,000 "bottom trailers" and 10,000 "surface drifters" :-

$\begin{array}{lcc}\quad & \begin{array}{c}10,000 \text { Bottom } \\ \text { Trailers. }\end{array} & \begin{array}{c}10,000 \text { Surface } \\ \text { Drifters. }\end{array} \\ \text { Bottles } & 75 \text { gross }=10,800 & 75 \text { gross } \\ \text { Corks } & 75 \text { gross } & 75 \text { gross } \\ \text { Marine Glue } & 1 \mathrm{cwt} .=50 \mathrm{kgm} . & 1 \mathrm{cwt} . \\ \text { Copper Wire } & 3 \mathrm{cwt} .=150 \mathrm{kgm} . & - \\ \text { Shot } & 8 \mathrm{cwt} .=400 \mathrm{kgm} . & - \\ \text { Cotton wool } & 32 \mathrm{lb} .=15 \mathrm{kgm} . & -\end{array}$

One man, with a boy to help him, can on the average make from fifty to seventy of each sort of bottle in a day of seven hours. 